\title{
Comment on Class in the U.S.
}

\author{
James G. Carrier ${ }^{1,2}$
}

Published online: 21 December 2017

(C) The Author(s) 2017. This article is an open access publication

In "Class in the U.S.," Durrenberger and Doukas take anthropologists to task for ignoring class in their research. That point is broadly correct, especially for the last quarter of the twentieth century. Here, I want to complicate an aspect of the paper's point that much of the basis of that ignoring reflects the ideology of meritocracy. That ideology has much to answer for, but also there have been changes within anthropology that facilitated that ignoring. They may be just as ideological as meritocracy, but they reflect different forces that operate in different ways. Also, because they are about anthropology, they cut closer to the disciplinary bone.

Their paper invokes Sherry Ortner, who "dismisses class as an 'objectivist' discourse" (p. 5) in favor of indigenous categories of identification. I invoke Ortner as well, but a different work: her "Theory in anthropology since the sixties" (Ortner 1984). In it she said that anthropology was dominated by a few schools of thought that stress structures and orders and ignore ordinary people, their lives, and their capacity to think and act. As she (1984: 148) put it, the important question that needs to be addressed is "the relationship(s) that obtain between human action, on the one hand, and some global entity which we may call 'the system,' on the other."

Ortner was hardly the only anthropologist to raise this question at the time, and different people tried to answer it in different ways. The answer that Ortner preferred was practice theory, and she invoked Pierre Bourdieu (1977). He had argued that a purely structural orientation reveals "the objective limits of objectivism" (1977: 1), but equally he rejected "the critique that naive humanism levels at scientific objectification in the name of 'lived experience' and the rights of 'subjectivity"' (1977: 3-4). Instead, he argued that we need to apprehend the structure or system that shapes the world that people experience, seek to understand, and to act within and on.

In the event, many in the discipline stopped trying to answer Ortner's question, jettisoned the idea of system, and focused instead on the lived experience. This was facilitated by the Cultural Turn, associated with the work of Clifford Geertz, especially his The interpretation of

James G. Carrier

jgc@jgcarrier.demon.co.uk

1 Max Planck Institute for Social Anthropology, Advokatenweg 36, 06114 Halle, Germany

2 Department of Anthropology, Indiana University, Bloomington, IN, USA 
cultures. There, Geertz (1973: 5) advocated a semiotic approach, concerned only with meaning, and urged us to focus on the substance of cultural expressions, his "texts," and only on them. As Adam Kuper (1999: 118) summarized it, "there is nothing outside the text", so that "if the texts pass over politics and economics in silence, then those matters can safely be ignored." Further, Geertz contrasted his approach with the sociological and the psychological, which, he (1973: 453) said, do not attend to those cultural meanings but seek "reductive formulas professing to account for them." For Geertzians, then, we should attend only to what is in the texts and we should not seek to account for that by relating them to anything outside of themselves.

When this was combined with postmodern and poststructural challenges to disciplinary authority and master narratives, many anthropologists felt themselves barred from anything beyond a sort of esthetic appreciation of the unfamiliar things that they encountered in their research, what Geertz (1973: 5) called "social expressions on their surface enigmatical." As Patricia Spyer (2011: 62) put it, we should avoid "any attempt to domesticate such otherness by either explaining it away or reducing it to something already known and commonsensical."

I have simplified a more complex story about how, over the course of the 1970s and 1980s, many anthropologists abandoned the older concern with structure, especially social structure, and instead contented themselves with seeking to describe, but not account for, people's culture, what they thought (see Carrier 2016: Chap. 2, 3). This newer orientation offered no tools for addressing what Ortner called objectivist notions such as class and no reason to be interested in them.

This sort of change in orientation was not, however, restricted to anthropology and the related disciplines of sociology and history. In addition, it occurred in what professed to be the hardest of the social sciences, economics, and I want to present very briefly what happened.

By the end of the Great Depression, the commanding heights in economics were occupied by varieties of Keynesian macroeconomics, which saw the economy as a system of related parts. As Keynes put it, "I have called my theory a general theory. I mean by this that I am chiefly concerned with the behaviour of the economic system as a whole" (Keynes 1973 [1936]: xxxii, in Milonakis and Fine 2009: 273). As well, Keynesians held that markets were best not left alone, for that could lead to trouble, such as the Great Depression. Rather, economists need to understand how the economy operates so that they can devise policies that will help assure the public welfare.

Thus it was that economics was dominated by a concern with system and how it works, as was the case with anthropology as Ortner described it. Also as was the case with anthropology, this began to unravel. In the 1960s and 1970s dissident economists urged a return to the older microeconomics, renamed "neoclassical economics." Their moment came in 1973, when many Western countries experienced "stagflation," a combination of economic stagnation and inflation. Led most visibly by Friedrich von Hayek (1974) in his Nobel Prize lecture, those dissidents argued that this revealed the inadequacy of Keynesian macroeconomics. The critics did not argue that we need a better macroeconomics, but said that all such were flawed simply because they were macroeconomic, concerned with the economic system and how it operates. They repeated von Hayek's (1944: 204) advice from 30 years earlier that governments should resist "the craving for intelligibility" about how the economy operates and why: failure to do so was to head down what he (1944) called The road to serfdom.

The ascendant neoclassical economists, then, rejected the idea of system in favor of markets, which they approached in ways that resembled what many anthropologists advocated. They treated people's market preferences simply as given, not to be either analyzed or 
explained, and treated market transactions as the expression of those preferences. Further, in restricting their attention to markets and transactions, they conformed to the Geertzian injunction that we look for neither causes nor consequences, that we do not, like those discredited Keynesians, seek reductive formulas that profess to account for what goes on.

I said at the outset that I wanted to complicate an aspect of "Class in the U.S.," its description of the things that led anthropologists generally to ignore class. Durrenberger and Doukas point to the ideology of meritocracy, which permeated American society. Here I have described intellectual changes within anthropology that made the objectivist study of social systems, including class systems, more difficult and even suspect. As well, however, I have shown that the discipline of economics experienced similar intellectual changes.

This parallel between disciplines as far apart as anthropology and economics suggests that there was a broader shift in intellectual orientation in the closing decades of the twentieth century. That shift meant that scholars decreasingly interpreted what they observed in their research in terms of large-scale things like society and economy, redolent of system, and increasingly interpreted what they observed in terms of individuals. For anthropologists, the pertinent aspects of those individuals were their cultural orientations and constraints and for economists they were their preferences and resources; for meritocrats, they were their ability and application.

In making this point, I complement "Class in the U.S." The authors point out that anthropologists' academic practice is shaped by the ideology of meritocracy. I complement that by suggesting that anthropologists consider the possibility that their intellectual orientations also have been shaped by another ideology, individualism.

Acknowledgements Open access funding provided by Max Planck Society.

Open Access This article is distributed under the terms of the Creative Commons Attribution 4.0 International License (http://creativecommons.org/licenses/by/4.0/), which permits unrestricted use, distribution, and reproduction in any medium, provided you give appropriate credit to the original author(s) and the source, provide a link to the Creative Commons license, and indicate if changes were made.

\section{References}

Bourdieu, Pierre. 1977. Outline of a theory of practice. Cambridge: Cambridge University Press.

Carrier, James G., ed. 2016. After the crisis: anthropological thought, neoliberalism and the aftermath. London: Routledge.

Geertz, Clifford. 1973. The interpretation of cultures. New York: Basic Books.

von Hayek, Friedrich A. 1944. The road to serfdom. London: Routledge.

von Hayek, Friedrich A. 1974. The pretence of knowledge. Nobel prize lecture (11 Dec.). www.nobelprize. org/nobel_prizes/economics/laureates/1974/hayek-lecture.html. Accessed 5 Aug. 2015.

Keynes, John Meynard. 1973 (1936). The general theory of employment, interest and money. London: Macmillan.

Kuper, Adam. 1999. Culture: the anthropologists' account. Cambridge, MA: Harvard University Press.

Milonakis, Dimitris, and Ben Fine. 2009. From political economy to economics. London: Routledge.

Ortner, Sherry. 1984. Theory in anthropology since the sixties. Comparative Studies in Society and History 26: 126-166.

Spyer, Patricia. 2011. What ends with the end of anthropology? In The end of anthropology?, eds. Holger Jebens and Karl-Heinz Kohl, 61-80. Wantage: Sean Kingston. 